\title{
THE RESEARCH ON THE POTENTIAL AERIAL TRAMWAY USERS' ATTITUDES, OPINIONS AND REQUIREMENTS - EXAMPLE: BELGRADE, SERBIA
}

\author{
Predrag Živanović, Slaven Tica, Branko Milovanović, Stanko Bajčetić, Andrea Nađ
}

Preliminary communication

The evolution of different urban public transport modes is pushed by different user demand levels, urban environment patterns and even natural constraints and barriers. The desire to overcome geographical and topographical barriers such as mountains, valleys and water, which cannot be efficiently served by conventional transport modes (bus, trolleybus, tram, metro, etc.), led to the introduction of aerial tramways or aerial cable-cars. Aerial tramway system is defined as the transportation technology that moves people in motor-less, engine-less vehicles that are propelled by a steel cable. Although technical, technological and economic aspects of aerial tramway introduction are well documented, very little effort has been made in defining the optimal market for this transport mode. The aim of this paper is to define potential aerial tramway users' attitudes, opinions and requirements. Specific methodology is defined taking into account the differences and particularities of each user group: citizens, domestic and foreign visitors. Methodology is applied in Belgrade, Serbia.

Keywords: aerial tramway; opinions; requirements; urban public transport; users' attitudes

Istraživanje stavova, mišljenja i zahtjeva potencijalnih korisnika žičare - primjer: Beograd, Srbija

Prethodno priopćenje

Razvoj različitih podsustava javnog gradskog prijevoza je uzrokovan različitim razinom zahtjeva korisnika, okruženjem i prirodnim ograničenjima i preprekama. U želji da se prevladaju zemljopisne i topografske prepreka kao što su planine, doline i vode, koje se ne mogu učinkovito savladati uobičajenim načinima prijevoza (autobus, trolejbus, tramvaj, metro, itd.), dovelo je do uvođenja žičara ili antenski kabel-automobila. Žičara se definira kao transportna tehnologija u kojoj se korisnici transportiraju u kabinama bez motora malih dimenzija koje pokreće čelični kabel. Iako su tehnički, tehnološki i ekonomski aspekti uvođenja žičare dobro dokumentirani, vrlo malo truda je napravljeno u definiranju optimalnog tržišta za ovu vrstu transporta. Cilj ovog rada predstavlja definiranje stavova, mišljenja i zahtjeva potencijalnih korisnika žičare. Specifična metodologija je definirana, koja uzima u obzir razlike i posebnosti svake skupine korisnika: građana, domaćih i stranih posjetitelja. Metodologija je primijenjena u Beogradu, Srbiji.

Ključne riječi: javni gradski prijevoz; mišljenja; stavovi korisnika; zahtevi; žičara

\section{Introduction}

A multimode city transport system consists of a number of subsystem modes functioning in an urban area with the aim of satisfying the needs of all city dwellers. The modes can be integrated between themselves, but not necessarily. A balanced city transport system is an integrated transport system designed and functioning so that each of the subsystems in synergy with others contributes to the maximum efficiency and quality of the whole system. In other words, different subsystem modes are coordinated so that users can travel easily combining a number of modes, while each mode has the most physically and operatively suitable role.

Several unconventional passenger transport technologies and modes that are designed to deal with specific functions have found significant applications in many areas around the world [1]. One of these technologies that is being used in areas with geographical and topographical barriers is Aerial tramway or Aerial Cable-car, sometimes called Aerial Ropeway Passenger transport (ART) or Cable Propeller Passenger transport (CPT). Aerial tramway is an aerial public passenger transport technology in which cabins (also called carriers, vehicles or cars) are suspended and propelled from above by cables [2]. Popularity of aerial tramway have risen even in big metropolitan areas, such as in London where the public transport network now includes National Rail, the Underground, Docklands Light Railway, a dense bus network, and even an urban cable car [3]. A similar system has already been built in other South American cities, such as Caracas, Venezuela and Rio de Janeiro,
Brasil. In Medellín, Colombia, aerial tramway was introduced in 2004 and network consists of three lines [4].

Although a number of authors wrote about aerial tramway technique and technology (maybe most comprehensive view can be found in [5], but also in [6], [7] and [8], as well as the current and future development tendencies of this transport subsystem [9], there is a limit number of research dealing with defining the service market, user travel behaviour and patterns, or with needs and requirements in aerial tramway subsystem [4]. On the other hand, this kind of research is common in other transport modes and the importance of understanding users and markets is readily apparent $[10 \div 15]$.

The transport service market is complex in its nature and it has a number of involved participants (stakeholders) with a range of heterogeneous needs, wishes, motives, along with their interests (objectives, demands and limitations) and their different expectations, views and types of behaviour. It is extremely difficult to satisfy a whole range of stakeholders' wishes. The process of market segmentation is a complex activity which should be performed in three basic phases:

1. The first phase consists of the analysis which includes understanding the market and ideas about how to use the market in the best way, as well as creating the basic segmented market structure. This phase includes reviewing your own services (services offered by the aerial tramway subsystem) as well as competitors' services offered by the other urban transport modes (public transport (PT), walking, cycling, private cars etc.)

2. The second phase consists of the analysis which includes the research and understanding of passengers' 
behaviour. This phase actually includes the behavioural analysis of the users, with the precise data about the travel purpose which later serve to define the quality of the service.

3. The third phase represents the defining of the typical consumer groups (consumer structure) and the research on their characteristics in the observed time period, which represents the basis for further designing, production and selling of transport services. This phase defines the typical social and economic groups of consumers and the characteristics of their behaviour, which by themselves represent the target market with which the system will do business in the future, both individually and as a whole.

The market opportunity analysis (MOA) can help decision makers assess each factor and thus offer guidelines for developing a practical approach to evaluate market opportunities [15]. Woodruf and Gardial [16] propose an MOA framework divided in four phases. The first phase of this framework (macro environmental analysis) aims to indicate how market opportunities are being shaped by economic, cultural, social, technological, governmental and natural forces. The second phase (enduser market analysis) identifies markets and customers with specific opportunities. The third phase consists of end-user value analysis, channel customer value analysis, competition analysis and supplier analysis. It aims to distinguish the nature and dynamics of the interactions between key participants in markets. The fourth phase concentrates on demand forecasting to evaluate the opportunities of entering identified markets.

These analyses can partly be performed on the basis of the standard information of the service area, and the other part by applying the specific research methods in a real transport system, especially the analysis related to the users' characteristics, their behaviour and requirements regarding the service quality.

Travel surveys are one of the most important ways of obtaining critical information needed for transportation planning and decision making, as well as for analysing transport service market [13]. Current information about the demographic, socioeconomic, and trip-making characteristics of individuals and households are gathered through these surveys [14]. These travel surveys are also important in evaluating changes in transportation supply and regulation as they occur [12]. Moreover, Commins and Nolan highlighted the importance of individual demographic and socioeconomic characteristics (gender, age, education, income, household size, license ownership, vehicle and parking accessibility), as well as travel variables such as availability, travel time and car ownership in explaining modal choice [17]. Mode attributes strongly relevant in mode choice behaviour are also discussed in available literature [18].

Different methods are used in travel and user behaviour surveys. Traditionally, methods such as telephone and face-to-face interviews, computer-based reporting to maintain a diary and passenger counting are used [19]. Hensher and Rose [11] highlighted that for new mode alternatives, stated choice (SC) is the best suited method as it offers the opportunity to establish the preferences of travellers for existing and new modal offerings under varying packages of influencing modal attributes. The literature on the design of stated choice experiments is extensive and growing [20] and [21], with substantial developments in the methods used to construct designs that are optimal in both the statistical and the behavioural sense [11] have defined trip attributes in stated choice design for existing public transport modes and for new public transport modes. Although these methods are still considered as reliable, a new trend of using GPS devices in conjunction with traditional surveys has emerged recently [13] and [22].

The aim of this paper is to determine the potential users' attitudes, opinions and requirements for the aerial tramway transport subsystem. First, brief analysis of Belgrade public transport system is given followed by the analysis of the transport service market and the key interest groups in the system are singled out. Thereafter, the research methodology for each of the specific users' group is defined: for citizens, domestic and foreign visitors. The research was conducted in the transport system of the city of Belgrade, Serbia. We finish with some concluding comments.

\section{Public transport in Belgrade - facts and figures}

The urban public passenger transport system in Belgrade is one of the greatest transport systems in SouthEastern Europe and it consists of four subsystems: bus, trolleybus, tramway and suburban rail subsystems.

The line network consists of more than 364 regular lines in daily traffic, with total length of 8500 kilometres:

- tram subsystem, with 12 lines and total length of 127,3 kilometres;

- trolleybus subsystem, with 8 lines and total length of 58,1 kilometres;

- city bus subsystem, with 119 lines and total length of 1800,4 kilometres;

- suburban bus subsystem, with 225 lines and total length of 6471,3 kilometres;

- urban rail system, one line with length of 23,6 kilometres;

- suburban rail subsystem, with 11 lines and total length of 489,3 kilometres.

The total number of passengers transported by the urban public passenger transport system in Belgrade is 2 539773 passengers a day and the largest share in transport operation has the bus subsystem, which transports 2118021 passengers a day $(83,39 \%)$, then the tram subsystem with 244199 transported passengers a day $(9,61 \%)$ and the trolleybus subsystem with 150355 transported passengers a day $(5,92 \%)$. Annual number of passengers transported by Belgrade's urban public passenger transport system is 685 million.

\section{The methodology}

The task of planning and design a public transport network from scratch is rarely presented. Most cities have some form of public transport system and the main challenge is to define the key strategies and tactics to improve it. The introduction of aerial tramway subsystems as part of the public transport system in 
Belgrade was undoubtedly an imaginative leap, with no urban precedent and considerable local cynicism regarding the proposal. These facts have influenced the research methodology.

The first step of the methodology is the definition of research objectives as determining the potential users' attitudes, opinions and requirements regarding the proposed implementation of the aerial tramway transport subsystem in Belgrade. Two possible corridors are suggested. First, aerial tramway line is planned between the high positioned Banovo Brdo, Ada Ciganlija (the most attractive recreation and tourist location) and the lowlands of Novi Beograd. The second line should connect the city centre and Zemun.

Selected corridors have influenced the research scope regarding spatial distribution of research points. This is defined in the second step of the methodology. A total of 18 city-wide interview points were selected including the cities biggest attraction centres (pedestrian area of Knez Mihajlova st; Kalemegdan; Skadarlija; river banks Zemun, 25. maj, Sava blocks; Ada Ciganlija lake; Košutnjak; Mountain Avala) and main transport transfer nodes - Belgrade bus station, Main rail station, Airport "Nikola Tesla", etc.

Temporal representativeness of the survey sample was achieved by the corresponding structure of interviewees per hours in a day, as well as by doing the research in the characteristic (peak) months of the year (July and August) for aerial tramway system.

Especially sensitive step was the defining of user groups. The main purpose of the new aerial tramway subsystem is to serve both as an attraction point as well as a new mode to satisfy users' mobility needs. Therefore, users are divided into three different groups: citizens, domestic visitors and foreign visitors. This is done in the third step of methodology. The number of interviewees for each user group is defined according to population size and minimal sample scopes required for the statistical analysis.

Next was selection of the research method. Combination of two research methods is used, direct and indirect interview, in order to cover all user groups and reach the desired scope.

The final step is research result presentation and analysis. Firstly, descriptive characteristics of the data are analysed. This was followed by comparison between the user groups for statistical significance using Chi Squared test. A starting hypothesis for all socio-demographic and trip characteristics is that survey results are independent of user groups.

\section{Defining the interest groups in the aerial tramway subsystem}

The requirements and goals for the aerial tramway subsystem should be formulated generally, according to the objectives and demands of all the inhabitants, based on the broad range of demands and goals relevant to all aspects of life. This is the reason for the careful research on the demands of the interest groups concerning the urban public transport system.

The requirements and goals for the aerial tramway subsystem can be drawn up on the basis of the requirements and goals of four interest groups (key stakeholders): users, transport companies - operators, local authorities and industry.

The subject of this paper is examining the attitudes, opinions and characteristics of the first group, i.e. the users of the aerial tramway subsystem, who can be divided into three subgroups:

- $\quad$ citizens - the city dwellers;

- domestic visitors - a relatively numerous category of potential users, attracted by Belgrade sites on the daily basis;

- foreign visitors - an especially interesting category of potential users which should have a much more significant place in the city's tourist offer, and will certainly benefit from the planning of the introduction of the aerial tramway system into the city transport system.

Main reason for above aerial tramway users' classification is that visitor (tourist) users of PT are a group distinct from resident users. This is well documented in literature [23] and [24]. Other studies provide some insights into the profile of tourist users of PT in rural areas $[25,26,27]$. However, the visitor users of PT in cities remain little known until recently. LeKlähn et al. [23] gave detailed factor analysis of visitor motivations for using as well as for not using PT in Munich.

\section{Method}

The research on requirements and goals of the user groups asks for the application of specific research methods. In order to generate the largest number possible of respondents, the survey was carried out at the most popular tourist sites in the City of Belgrade, as well as at the existing PT stops and stations.

Combination of two research methods is used: direct and indirect interview. In direct interview, the survey assistant approached the respondents, introducing himself/herself and briefly outlining main goals of the research project, and inviting them to participate in the survey. Respondents were randomly recruited. In indirect interview, questionnaires were left out on research sites for user to take them, fill them and return questionnaires on the same site.

For all user groups structured questionnaires are made using stated choice method. Questionnaires for each user group were the same regardless of research method (direct or indirect interview).

The method of researching the city dwellers was the direct interview - the polls were given at the chosen sites (centres of attraction).

The methods of administering surveys of domestic and foreign visitors were via direct interviews at the specific sites (centres of attraction) and indirect interviews in the facilities for tourist accommodation (hotels, motels and hostels).

\section{$5 \quad$ Research results}

The research results are divided into three parts. For each group of users we outlined their characteristics, 
attitudes, opinions and requirements for the aerial tramway subsystem in Belgrade. The complete results are given in Appendix A.

\subsection{The citizens}

The city of Belgrade inhabitants are the biggest part of the interviewees in the total sample of those polled. The total number of 2420 people was surveyed. This group represents the broadest category of the potential users of aerial tramway.

The research method was the direct interview, and the poll form had three parts. The first part (social characteristics questions) included the questions concerning the age and professional structure of the users. The second group (travel characteristics questions) included the information about the actual travel of the interviewees: origin and destination of travel, the purpose of travel, the transport mode and the travel frequency. The purpose of the third group of the questions (aerial tramway related questions) was to obtain the city dwellers' attitudes and opinions about the aerial tramway: about the needs and possibilities for introducing this subsystem, their willingness to use aerial tramway and the main reasons for using them. The city dwellers also stated their opinions about the frequency of the possible aerial tramway use and the purpose of travel for which they would use the aerial tramway subsystem as the transport mode. Since aerial tramway is subsystem of the PT system, a special research was done on the relation between the possible aerial tramway service price and the PT service price, as one of the key factors for modal split.

The citizens showed extreme willingness to use the aerial tramway subsystem; as many as $92,49 \%$ of them would use this subsystem. Half of them stated shorter time and length of travelling as reasons, and the other reason was the subjective (unique) experience of travelling by aerial tramway. An average potential aerial tramway user is employed $(40,27 \%)$, aged 19 to 30 $(43,79 \%)$ and user of the PT system $(48,67 \%)$. The dominant purpose of travelling by aerial tramway is recreation and fun $(52,40 \%)$, and the frequency of use is a few times a week $(33,17 \%)$, during the summer $(58,21$ $\%)$. Moreover, majority of citizens $(90,63 \%)$ thinks that city tourist offer will be improved with introduction of this new transport mode.

Most of the city dwellers stated that the acceptable price for using aerial tramway was the price of the PT $(45,25 \%)$. However, there was a surprisingly high percentage of those who agreed to accept a higher price for using aerial tramway than the price of using the PT system $(35,79 \%)$. The remaining percentage of the city dwellers $(18,96 \%)$ declared that the price for using the aerial tramway had no relevance to them. The research results showed that a citizen of Belgrade was willing to pay an average price of 0,81 Euro for one aerial tramway trip. Employed citizens would pay even more (0,85 Euro), while senior citizens are willing to give 0,70 Euro per single aerial tramway ride. This information is significant for creating tariff policy and determining the level of the service price.

\subsection{Domestic visitors}

Domestic visitors, as the potential users of the aerial tramway system, were surveyed using specifically prepared questionnaires. The poll was carried out at the chosen sites (centres of attraction) - direct interview, as well as in hotels and hostels, where the poll forms were left for the users (the method of the indirect interview).

In order to determine the representative sample of domestic visitors, comprehensive research was carried out in relation to their number and total of overnights they had realized in Belgrade over the period of the five years. The total number of domestic visitors who visited Belgrade per year amounted to 190 000, and there were 494000 overnights. Peak period is in the summer (July and August), i.e. in the period when the research was carried out. The total number of interviewees amounted to 777.

The poll form consisted of three interdependent parts. The first part (social characteristics questions) included the questions concerning the age and professional structure of domestic visitors. The purpose of the second group of the questions (travel related questions) was to obtain the information about the characteristics of the actual travel of the interviewees: the place they came to Belgrade from, way and frequency of travel, length of stay and locations they were going to visit in Belgrade. The purpose of the third group of the questions (aerial tramway related questions) was to obtain the attitudes and opinions about aerial tramway transport: about the needs and possibilities for introducing this subsystem, their willingness to use ropeways and the main reasons for using them.

More than a half of domestic visitors were 19 to 30 years of age, i.e. $54,45 \%$ of them. This is in correspondence with results of other similar studies on tourists as PT users $[28,29,30]$. Most of them were the employed $(37,03 \%)$ and students $(29,42 \%)$, those who came to Belgrade on business $-35,99 \%$ and to do their private business $-28,80 \%$. The greatest number of visitors stayed in Belgrade for a day, $56,14 \%$ of them, which meant that most of the domestic visitors who visited Belgrade were actually daily migrants. Domestic visitors came to Belgrade mostly by bus $(50,00 \%)$ and by train $(37,63 \%)$, while only $10,81 \%$ of them came to Belgrade by car.

The biggest number of domestic visitors visited Kalemegdan (22,86\%) and the city center (18,23\%), while "the city sea" Ada Ciganlija was another attractive zone and was visited by $12,48 \%$ of domestic visitors.

When it comes to the aerial tramway related questions, domestic visitors showed very high willingness for using this subsystem, as many as $92,91 \%$ of them. Among them, 62,24\% would use the aerial tramway because of the unique experience it offered, while $36,13 \%$ would use the aerial tramway because of the shorter connection to the other parts of the city. Furthermore, this new transport mode will improve city tourist offer as it is recognized by $92,54 \%$ of domestic visitors.

Most of the domestic visitors thought that the acceptable price for using aerial tramway was the same as the price of the public city transport $(41,14 \%)$. There was an extremely high percentage of those who agreed to 
accept a higher price for using aerial tramway than the price of using the PT system - as many as $37,24 \%$, with the average price of 1,02 Euro for single ride by aerial tramway. The remaining $21,62 \%$ of domestic visitors would use the aerial tramway regardless of the price.

\subsection{Foreign visitors}

The objective of interviewing foreign visitors was determining their attitudes and opinions about the possibility for introducing the aerial tramway system and similar systems for the transportation of passengers.

The method was the direct interview - a poll (a questionnaire composed in English and Serbian). The poll form consisted of three parts, very similar as for surveying the domestic visitors.

The research was carried out at characteristic sites (centres of attraction): Knez Mihailova, Kalemegdan, The Railway Station, the bus station BAS; in the information centres of the Tourist Organization of Belgrade ("Nikola Tesla" Airport, Terazije passage, Makedonska Street and the Railway Station); as well as on the pier nearby the Jugoslavija hotel - polling the users of the organized city sightseeing by boat.

The other research method was the indirect interview (where the questionnaire was the same as the one for the direct interview) in the chosen facilities for the accommodation of visitors (hotels, motels and hostels). The poll forms were distributed to the facilities for the accommodation of visitors, whose task was to forward them to their guests and to deliver the filled forms to the research team.

The total number of the interviewed foreign visitors was 789, and the sample representativeness was determined by trend analysis of the foreign visitors' number and their structure over the five years period. In the observed period, Belgrade was visited by about 400000 foreign visitors a year, who made 825000 overnights a year. The biggest number of visitors came from Slovenia, Germany, Italy, Greece, Great Britain, Croatia, the USA and Austria.

The visitors stayed in Belgrade for 2,05 days on average. Part of the total number of visitors that visit Belgrade (estimated at 45000 visitors) is not statistically recorded because these are visitors cruising the Danube by big ships and do not use hotel or other accommodation. This information was confirmed in the poll which showed that in more than $45 \%$ of situations visitors stayed in Belgrade for 2 or 3 days, while 20,56\% of them spent only one day in Belgrade or were just passing by.

Young people aged 19 to 30 were the most frequent visitors in Belgrade $(57,20 \%)$ which ones again supports above mentioned fact that tourists are generally of a younger age. Almost $90 \%$ of foreign visitors were the employed and students, which had the share of $46,37 \%$ and $41,91 \%$ respectively.

Foreign students most often stayed in hotels $(69,40$ $\%)$. During their stay in Belgrade, half of the foreign visitors $(50,43 \%)$ visited cultural places and tourist sites, and $14,54 \%$ of them visited the recreation (entertainment) facilities, restaurants and famous Belgrade rafts. According to the way of movement, most foreign visitors walked (48,70\%), and $19,30 \%$ of them used PT.

More than $85 \%$ of foreign visitors would use aerial tramway, and the main reason would be shorter travel time to particular city parts $(48,70 \%)$ or the unique subjective experience of travelling by aerial tramway $(45,50 \%)$.

\subsection{Statistical significance analysis}

Comparison between the user groups was checked for statistical significance using Chi Squared test. For all demographic and trip characteristics starting hypothesis is that survey results are independent of user groups. All hypotheses are tested with significance level at $\alpha=0,01$. Results are given in Tab. 1.

Table 1 Significance level analysis results using Chi Squared test

\begin{tabular}{|l|c|c|c|}
\hline \multicolumn{1}{|c|}{ Characteristics } & $\begin{array}{c}\chi^{2} \\
\text { value }\end{array}$ & $\begin{array}{c}\text { Degrees } \\
\text { of } \\
\text { freedom }\end{array}$ & Result \\
\hline $\begin{array}{l}\text { The age structure of aerial } \\
\text { tramway users }\end{array}$ & 150,40 & 10 & $\begin{array}{c}\text { Hypothesis } \\
\text { rejected }\end{array}$ \\
\hline $\begin{array}{l}\text { The structure of users by } \\
\text { occupation }\end{array}$ & 288,68 & 10 & $\begin{array}{c}\text { Hypothesis } \\
\text { rejected }\end{array}$ \\
\hline $\begin{array}{l}\text { The structure of users by visit } \\
\text { duration in Belgrade }\end{array}$ & 330,28 & 4 & $\begin{array}{c}\text { Hypothesis } \\
\text { rejected }\end{array}$ \\
\hline $\begin{array}{l}\text { The structure according to } \\
\text { users' willingness to use } \\
\text { aerial tramway }\end{array}$ & 40,21 & 2 & $\begin{array}{c}\text { Hypothesis } \\
\text { rejected }\end{array}$ \\
\hline $\begin{array}{l}\text { Structure of the reasons for } \\
\text { users to use aerial tramway }\end{array}$ & 78,34 & 6 & $\begin{array}{c}\text { Hypothesis } \\
\text { rejected }\end{array}$ \\
\hline $\begin{array}{l}\text { Structure of users according } \\
\text { to the price they would pay } \\
\text { for single ride by aerial } \\
\text { tramway }\end{array}$ & 4,18 & 2 & $\begin{array}{c}\text { Hypothesis } \\
\text { accepted }\end{array}$ \\
\hline $\begin{array}{l}\text { Users' opinion on whether the } \\
\text { city tourist offer will be } \\
\text { improved with aerial } \\
\text { tramway introduction }\end{array}$ & 2,62 & 2 & $\begin{array}{c}\text { Hypothesis } \\
\text { accepted }\end{array}$ \\
\hline
\end{tabular}

Chi Squared test has shown that age and occupations structure of main user groups are significantly different for each of these groups. Therefore, independence hypothesis is rejected. Duration of visiting Belgrade is also different for domestic and foreign visitor and null hypothesis is rejected as well.

Although all user groups stated extremely high willingness to use the aerial tramway system it could not be concluded that this willingness is independent to user group. This hypothesis is also rejected, as well as the one regarding reasons to use aerial tramway. This has raised issue of possibility to predict transport demand.

The acceptable price for using aerial tramway is independent of user group, i.e. hypothesis is accepted. Most of them would accept the same price as for PT or even a higher price. This information is significant for creating tariff policy and determining the level of the service price. Moreover, user groups' attitude about whether the city tourist offer will be improved with aerial tramway introduction is also consistent and independent. Null hypothesis is also accepted. 


\section{Conclusions}

Delivering sustainable PT system requires constant improvements and innovations. Introduction of new PT modes can be a good tool to accomplish this goal. First step in this process is market analysis and defining potential users. Methodology given in this paper can be used to define target user groups for aerial tramway. The research was conducted in the summer period according to the preconceived methodology of polling passengers (travellers).

Case study in Belgrade showed that three main potential user groups are very affirmative about the introduction and development of aerial tramway. Such high percentage of the positive interest in this transport mode clearly showed the need for construction and introduction of aerial tramway into the public transport system of Belgrade. The main reasons for using aerial tramway are shorter links with other parts of the city and unique experience of aerial tramway ride. Moreover, research results include the frequency of travelling with this PT mode.

It can also be concluded that the number of potential aerial tramway users is generally irrelevant to price for a single trip. All users would pay two or even three times more than for a single trip by other PT modes. This information is very significant for creating tariff policy and determining the level of the service price in order to provide basis for quality feasibility study with financial and economic elements.

Though carefully planned and conducted, this study is not without limitations. Results should not be taken for granted as people generally support the construction of a new transport system in their city, but that does not mean they will also actually use it when the system has been constructed. Despite these limitations, the paper has shed light on the reasons for use of aerial tramway by different user groups. It identifies the distinctions and similarities between the main user groups (in this case, the domestic and foreign visitors and citizens), which would provide basis for further studies on use of aerial tramway. The other advantage of the methodology is that it gives a good insight of the user requirements regarding the new transport mode. Some of these data can provide a basis for feasibility or similar study.

The methodology can be applied for potential market analysis when introducing new transport modes in other cities. However, some methodology steps are highly correlated to the purpose and hierarchical place of the new subsystem in the urban transport system, i.e. selection of research points, defining the user groups, etc.

\section{Acknowledgements}

This paper is based on the project TR36027: "Software development and national database for strategic management and development of transportation means and infrastructure in road, rail, air and inland waterways transport using the European transport network models" which is supported by the Ministry of science and technological development of the Republic of Serbia (2011-2016).

\section{References}

[1] Vuchic, V. Urban Transit Systems and Technology. Hoboken NJ: Wiley, 2007.

[2] Alshalalfah, B.; Shalaby, A.; Dale, S.; Othman, F. Aerial Ropeway Transportation Systems in the Urban Environment: State of the Art. // Journal of Transportation Engineering - ASCE. 138, 3(2012), pp. 253-262.

[3] Hickman, R.; Hall, P.; Banister, D. Planning more for sustainable mobility. // Journal of Transport Geography. 33(2013), pp. 210-219.

[4] Brand, P.; Davila, J. Aerial cable-car systems for public transport in low-income urban areas: lessons from Medellin, Colombia. // 3rd World Planning Schools Congress (Track 11: Transportation, Infrastructure and Planning) / Perth, 2011

[5] Brownjohn, J. W. Dynamics of aerial cableway system. // Engineering Structures. 20, 9(1998), pp. 826-836.

[6] Neumann, E. Cable Propelled People Movers in Urban Environments. // Transportation Research Record: Journal of the Transportation Research Board. 1349(1992), pp. 125132.

[7] Bryja, D.; Knawa, M.; Computational model of an inclined aerial ropeway and numerical method for analyzing nonlinear cable-car interaction. // Computers \& Structures. 89, 21-22(2011), pp. 1895-1905.

[8] Alshalalfah, B.; Shalaby, A.; Dale, S.; Othman, F. Improvements and Innovations in Aerial Ropeway Transportation Technologies: Observations from Recent Implementations. // Journal of Transportation Engineering ASCE. 139, 8(2013), pp. 814-821.

[9] Neumann, E. The Past, Present and Future of Urban CablePropelled People Movers. // Journal of Advanced Transportation. 31(1999), pp. 51-82.

[10] Grdzelishvili, I.; Sathre, R. Understanding the urban travel attitudes and behavior of Tbilisi residents. // Transport Policy. 18, 1(2011), pp. 38-45.

[11] Hensher, D. A.; Rose, J. M. Development of commuter and non-commuter mode choice models for the assessment of new public transport infrastructure projects: A case study. // Transportation Research Part A. 41(2007), pp. 428-443.

[12] Griffiths, R.; Richardson, A. J.; Lee-Gosselin, M. E. H. Travel surveys, transportation in the new millennium. // Transportation Research Board 79th Annual Meeting / Washington DC, 2000.

[13] Bolbol, A.; Cheng, T.; Tsapakis, I. A spatio-temporal approach for identifying the sample size for transport mode detection from GPS-based travel surveys: A case study of London's road network. // Transportation Research Part C: Emerging Technologies. 43, 2(2013), pp. 176-187.

[14] Bolbol, A.; Cheng, T.; Tsapakis, I.; Haworth, J. Inferring hybrid transportation modes from sparse GPS data using a moving window SVM classification. // Computers, Environment and Urban Systems. 36, 6(2012), pp. 526-537.

[15] Hua-An, L.; Rong-Rong, L. Market opportunity analysis and evaluation of the expansion of air transport services across the Taiwan Strait. // Journal of Air Transport Management. 37(2014), pp. 10-19.

[16] Woodruff, R. B.; Gardial, S. F. Know Your Customer. New Approaches to Understanding Customer Value and Satisfaction. Cambridge: Blackwell Publishers, Inc., 1996

[17] Commins, N.; Nolan, A. The determinants of mode of transport to work in the Greater Dublin Area. // Transport Policy. 18(2011), pp. 259-268.

[18] Cheea, W. L.; Fernandez, J. L. Factors that Influence the Choice of Mode of Transport in Penang: A Preliminary Analysis. // Procedia - Social and Behavioral Sciences. 91(2013), pp. 120-127. 
[19] Stopher, P. R.; Greaves, S. P. Household travel surveys: where are we going? // Transportation Research Part A: Policy Practice. 41, 5(2007), pp. 367-381.

[20] Louviere, J. J.; Hensher, D. A.; Swait, J. F. Stated Choice Methods and Analysis. Cambridge University Press, Cambridge, 2000.

[21] Hensher, D. A.; Rose, J.; Greene, W. H. Applied Choice Analysis: A Primer. Cambridge University Press, Cambridge, 2005.

[22] Stopher, P. R.; Metcalf, H. M. A. Methods for Household Travel Surveys. National Academy Press, Washington, DC, USA, 1996.

[23] Le-Klähn, D. T.; Gerike, R.; Hall, M. Visitor users vs. nonusers of public transport: The case of Munich, Germany. // Journal of Destination Marketing \& Management. 3, 3(2014), pp. 152-161.

[24] Kinsella, J.; Caulfield, B. An examination of the quality and ease-of-use of public transport in Dublin from a new comer's perspective. // Journal of Public Transportation. 14, 1(2011), pp. 69-81.

[25] Lumsdon, L. M. Factors affecting the design of tourism bus services. // Annals of Tourism Research. 33, 3(2006), pp. 748-766.

[26] Dallen, J. The challenges of diverse visitor perceptions: rail policy and sustainable transport at the resort destination. // Journal of Transport Geography. 15, 2(2007), pp. 104-115.

[27] Dallen, J. Sustainable transport, market segmentation and tourism: the Looe Valley Branch Line Railway, Cornwall, UK. // Journal of Sustainable Tourism. 15, 2(2007), pp. 180-199.

[28] Farag, S.; Lyons, G. To use or not to use? An empirical study of pre-trip public transport information for business and leisure trips and comparison with car travel. // Transport Policy. 20(2012), pp. 82-92.

[29] Quiroga, I. Characteristics of package tours in Europe. // Annals of Tourism Research. 17, 2(1990), pp. 185-207.

[30] Thompson, K. P.; Schofield, P. An investigation of the relationship between public transport performance and destination satisfaction. // Journal of Transport Geography. 15, 2(2007), pp. 136-144.

\section{Authors' addresses}

Predrag Živanović, $M S c, P h D$ candidate University of Belgrade,

Faculty of Transport and Traffic Engineering

Vojvode Stepe 305, 11000 Belgrade, Serbia

E-mail: p.zivanovic@sf.bg.ac.rs

\section{Slaven Tica, PhD, Associate professor}

University of Belgrade,

Faculty of Transport and Traffic Engineering

Vojvode Stepe 305, 11000 Belgrade, Serbia

E-mail: slaven.tica@sf.bg.ac.rs

Branko Milovanović, PhD, Assistant professor

University of Belgrade,

Faculty of Transport and Traffic Engineering

Vojvode Stepe 305, 11000 Belgrade, Serbia

E-mail: b.milovanovic@sf.bg.ac.rs

Stanko Bajčetić, MSc, PhD candidate

University of Belgrade,

Faculty of Transport and Traffic Engineering

Vojvode Stepe 305, 11000 Belgrade, Serbia

E-mail: s.bajcetic@sf.bg.ac.rs

\section{Andrea Nad, MSc, PhD candidate}

University of Belgrade,

Faculty of Transport and Traffic Engineering

Vojvode Stepe 305, 11000 Belgrade, Serbia

E-mail: andrea@sf.bg.ac.rs

\section{Appendix A: Selected research results}

Table 1 The age structure of aerial tramway users (in \%)

\begin{tabular}{|c|c|c|c|}
\hline Age (years) & Citizens & $\begin{array}{c}\text { Domestic } \\
\text { visitors }\end{array}$ & $\begin{array}{c}\text { Foreign } \\
\text { visitors }\end{array}$ \\
\hline$<18$ & 15,56 & 8,65 & 3,95 \\
\hline $19-30$ & 43,79 & 54,45 & 57,20 \\
\hline $31-40$ & 14,49 & 11,74 & 16,43 \\
\hline $41-50$ & 8,94 & 11,87 & 12,74 \\
\hline $51-60$ & 9,35 & 8,90 & 5,35 \\
\hline$>60$ & 7,86 & 4,39 & 4,33 \\
\hline Total & 100,00 & 100,00 & 100,00 \\
\hline
\end{tabular}

Table 2 The structure of users by occupation (in \%)

\begin{tabular}{|l|c|c|c|}
\hline \multicolumn{1}{|c|}{ Occupation } & Citizens & $\begin{array}{c}\text { Domestic } \\
\text { visitors }\end{array}$ & $\begin{array}{c}\text { Foreign } \\
\text { visitors }\end{array}$ \\
\hline Employed & 40,27 & 37,03 & 46,37 \\
\hline Pupil & 15,00 & 8,52 & 2,68 \\
\hline Student & 22,83 & 29,42 & 41,91 \\
\hline Senior citizen & 10,98 & 6,84 & 5,61 \\
\hline Unemployed & 10,02 & 17,81 & 2,68 \\
\hline Other & 0,91 & 0,39 & 0,76 \\
\hline Total & 100,00 & 100,00 & 100,00 \\
\hline
\end{tabular}

Table 3 The structure of users by visit duration in Belgrade (in \%)

\begin{tabular}{|l|c|c|c|}
\hline \multicolumn{1}{|c|}{ Duration } & \multirow{2}{*}{ Citizens } & $\begin{array}{c}\text { Domestic } \\
\text { visitors }\end{array}$ & $\begin{array}{c}\text { Foreign } \\
\text { visitors }\end{array}$ \\
\hline \multirow{4}{*}{ 1 day } & \multirow{4}{*}{$\begin{array}{c}\text { Not } \\
\text { 2-3 days }\end{array}$} & 56,14 & 20,56 \\
\cline { 1 - 1 } applicable & 12,14 & 45,18 \\
\cline { 1 - 1 } 4-7 days & 10,05 & 18,27 \\
\cline { 1 - 1 } 8-14 days & 3,39 & 7,36 \\
\cline { 1 - 1 } More than 14 days & 18,28 & 8,63 \\
\cline { 1 - 1 } Total & 100,00 & 100,00 \\
\hline
\end{tabular}

Table 4 Users' willingness to use aerial tramway (in \%)

\begin{tabular}{|l|c|c|c|}
\hline \multicolumn{1}{|c|}{ Willingness } & Citizens & $\begin{array}{c}\text { Domestic } \\
\text { visitors }\end{array}$ & $\begin{array}{c}\text { Foreign } \\
\text { visitors }\end{array}$ \\
\hline Yes & 92,49 & 92,91 & 85,48 \\
\hline No & 7,51 & 7,09 & 14,52 \\
\hline Total & 100,00 & 100,00 & 100,00 \\
\hline
\end{tabular}

Table 5 Structure of the reasons for users to use aerial tramway (in \%)

\begin{tabular}{|l|c|c|c|}
\hline \multicolumn{1}{|c|}{ Reason } & Citizens & $\begin{array}{c}\text { Domestic } \\
\text { visitors }\end{array}$ & $\begin{array}{c}\text { Foreign } \\
\text { visitors }\end{array}$ \\
\hline $\begin{array}{l}\text { Shorter links with other parts of } \\
\text { the city }\end{array}$ & 46,51 & 36,13 & 48,70 \\
\hline $\begin{array}{l}\text { Due to the unique experience } \\
\text { of aerial tramway ride }\end{array}$ & 49,96 & 62,24 & 45,50 \\
\hline Other reason & 2,46 & 0,65 & 2,84 \\
\hline Do not know why & 1,07 & 0,98 & 2,96 \\
\hline Total & 100,00 & 100,00 & 100,00 \\
\hline
\end{tabular}

Table 6 Structure of users by the purpose of using aerial tramway (in \%)

\begin{tabular}{|l|c|c|c|}
\hline \multicolumn{1}{|c|}{ Purpose } & Citizens & $\begin{array}{c}\text { Domestic } \\
\text { visitors }\end{array}$ & $\begin{array}{c}\text { Foreign } \\
\text { visitors }\end{array}$ \\
\cline { 1 - 2 } Work trips & 15,26 & & \\
\cline { 1 - 2 } School (Faculty) & 10,09 & & \\
\cline { 1 - 2 } Recreation/Fun & 52,40 & Not \\
Shopplicable & 7,39 & $\begin{array}{c}\text { Not } \\
\text { applicable }\end{array}$ \\
\cline { 1 - 2 } Private stuff & 3,28 & & \\
\hline Other & 11,58 & & \\
\hline Total & 100,00 & & \\
\hline
\end{tabular}


Table 7 Structure of users by time period of using aerial tramway (in \%)

\begin{tabular}{|l|c|c|c|}
\hline \multicolumn{1}{|c|}{ Time period } & Citizens & $\begin{array}{c}\text { Domestic } \\
\text { visitors }\end{array}$ & $\begin{array}{c}\text { Foreign } \\
\text { visitors }\end{array}$ \\
\cline { 1 - 2 } During whole year & 22,85 & \multirow{2}{*}{$\begin{array}{c}\text { Not } \\
\text { applicable }\end{array}$} & $\begin{array}{c}\text { Not } \\
\text { applicable }\end{array}$ \\
\cline { 1 - 2 } Only in summer & 58,21 & & \\
\cline { 1 - 2 } $\begin{array}{l}\text { Always when } \\
\text { weather is nice }\end{array}$ & 18,94 & 100,00 & \\
\hline Total & &
\end{tabular}

Table 8 Structure of users by: frequency of using aerial tramway (citizens) and frequency of visiting Belgrade (domestic visitors) (in \%)

\begin{tabular}{|c|c|c|c|}
\hline Frequency & Citizens & $\begin{array}{c}\text { Domestic } \\
\text { visitors }\end{array}$ & $\begin{array}{l}\text { Foreign } \\
\text { visitors }\end{array}$ \\
\hline Everyday & 21,11 & 10,95 & \multirow{6}{*}{$\begin{array}{c}\text { Not } \\
\text { applicable }\end{array}$} \\
\hline Few times a week & 33,17 & 9,10 & \\
\hline Only weekends & 13,67 & 2,37 & \\
\hline Few times a month & 18,25 & 35,62 & \\
\hline Rarely & 13,80 & 41,95 & \\
\hline Total & 100,00 & 100,00 & \\
\hline
\end{tabular}

Table 9 Structure of users according to the price they would pay for single ride by aerial tramway (in \%)

\begin{tabular}{|l|c|c|c|}
\hline \multicolumn{1}{|c|}{$\begin{array}{c}\text { Price of aerial } \\
\text { tramway single ride }\end{array}$} & Citizens & $\begin{array}{c}\text { Domestic } \\
\text { visitors }\end{array}$ & $\begin{array}{c}\text { Foreign } \\
\text { visitors }\end{array}$ \\
\cline { 1 - 3 } $\begin{array}{l}\text { Regardless of the } \\
\text { price }\end{array}$ & 18,96 & 21,62 & \\
\cline { 1 - 2 } $\begin{array}{l}\text { Same price as for } \\
\text { UPT }\end{array}$ & 45,25 & 41,14 & \multirow{2}{*}{$\begin{array}{c}\text { Not } \\
\text { applicable }\end{array}$} \\
\cline { 1 - 3 } $\begin{array}{l}\text { Higher price than for } \\
\text { UPT }\end{array}$ & 35,79 & 37,24 & \\
\cline { 1 - 3 } Total & 100,00 & 100,00 & \\
\hline
\end{tabular}

Table 10 Users' opinion on whether the city tourist offer will be improved with aerial tramway introduction (in \%)

\begin{tabular}{|l|c|c|c|}
\hline $\begin{array}{c}\text { Better city tourist } \\
\text { offer }\end{array}$ & Citizens & $\begin{array}{c}\text { Domestic } \\
\text { visitors }\end{array}$ & $\begin{array}{c}\text { Foreign } \\
\text { visitors }\end{array}$ \\
\hline Yes & 90,63 & 92,54 & \multirow{2}{*}{$\begin{array}{c}\text { Not } \\
\text { applicable }\end{array}$} \\
\cline { 1 - 3 } No & 4,51 & 3,60 & 3,86 \\
\hline Do not know & 4,85 & 100,00 & \\
\hline
\end{tabular}

